\title{
Demonstration of Making Sago (Metroxylon sagu Rottb.) Crackers with Variations in the Comparison of Sago Flour and Wheat Flour to High School Students
}

\author{
Sri Anggraeni, Hilda Yanuar Abadi, Siti Nur Hofifah, Sri Anggraeni, Risti Ragadhita, Asep Bayu Dani \\ Nandiyanto
}

Universitas Pendidikan Indonesia, Jl. Dr. Setiabudhi No. 229 Bandung, Indonesia

anggraeni_said@upi.edu, hildabadi090102@upi.edu, sitinurhofifah@upi.edu, ristiragadhita@upi.edu,nandiyanto@upi.edu

\begin{abstract}
The purpose of this study was to determine the learning outcomes of high school science students regarding the mechanical characteristic and chemical composition of food, especially sago (Metroxylon sagu Rottb.) crackers through learning video. This research was conducted by experimental demonstration through pre-test, video demonstration, and post-test. In addition, the method of making sago crackers is done through the process of mixing the raw material, kneading the material until it is smooth, shaping crackers, and baking crackers. The results showed that the hardness of the sago crackers decreases with the amount of sago flour content. In addition, the students' posttest scores increased significantly. Demonstration videos can convey information or events effectively without having to experience it firsthand. This research hopes that the method can facilitate an abstract material transfer, train student skills, and improve students' understanding of chemical composition's effect on food's mechanical characteristics. The other hope of this research is useful as a reference to enable distance learning.
\end{abstract}

Keywords: Sago Crackers, Wheat Flour, Sago Flour, Demonstration Experimental, Mechanical Properties

\footnotetext{
Asep Bayu Dani Nandiyanto

Departemen Pendidikan Kimia, Universitas

Pendidikan Indonesia, Jl. Dr. Setiabudi No. 229

Bandung, Indonesia

nandiyanto@upi.edu
}

\section{Introduction}

Experimental demonstration is one of a teaching method that can be used to convey abstract material to students. The experimental demonstration method using video can stimulate student interest and curiosity in the learning. The demonstration video can incease the student focus and make they easier to accept the abstract material (Nandiyanto, Raziqi, Dallyono, and Sumardi, 2020). This demonstration video is also suitable for use in distance learning, especially during the Covid-19 pandemic. Lot of abstract material can be conveyed using a video demonstration.

The experimental demonstration method can use to teach the mechanical characteristics of food. Studying the mechanical characteristics of food is an interesting and rare thing. The mechanical characteristics of food could be learned by students' high school and related to Biology subjects regarding the nutritional content and chemical composition of the food. One of the foods that can be used as material to teach the mechanical characteristics of food is the sago cracker.

Sago crackers are made from sago flour. Sago flour (Metroxylon sp.) is one of the staple foods in Indonesia especially in western Indonesia (Katsuya and Kadir, 2018; Tingginehe, Hadju, Djide, and Jafar, 2016). Sago crackers are widely liked as a school snack because they have dry and crunchy properties. Many factors can affect the characteristics of sago crackers, such as the production method and the chemical composition of the raw material (Nishio, Ito, Takata, Goshima, Matsushita, Nakamura, and Yamauchi, 2020). The chemical composition of the flour used to make sago crackers affects the mechanical characteristics of these crackers (Saeleaw and Schleining, 2010). To convey this abstract material (the mechanics characteristic of sago crackers) can use the experimental demonstration methods.

Research on using video as an experimental demonstration media has been widely used, as was done by Sever, Oguz-Unve, and Yurumezoglu (2013) which explains the effectiveness of using video with demonstration methods in presenting inquiry-based classroom experiments. Jokela, 
Nurmi, Genzwuerker, and Castrén, (2009) also used a short video clip to demonstrate the use of a laryngeal tube in medical training participants. Donkin, Askew, and Stevenson (2019), also use videos to teach skills in medical laboratories to science students based on online learning. In addition, Yusuf, Amin, and Nugrahaningsih (2017) also use videos to teach enzymes and metabolism material to high school students. The use of video as a medium in the experimental demonstration method shows a lot of good results to increase students' understanding of abstract concepts. However, there has been no research on the use of video through experimental demonstration methods to teach the mechanical characteristics of foods.

Therefore, the novelty of this study was to determine the learning outcomes of high school science students regarding the mechanical properties and chemical composition of food, especially sago crackers using experimental demonstration method through learning video. This research was conducted using experimental demonstration methods. Students who are the subject are given instructions to do the pre-test, watch video demonstrations, and do the post-test. The demonstration video contains a theory about the nutritional content and chemical composition and how it affects to sago crackers. Besides that, in the video is also presented how to make sago crackers with various ratios of sago flour and wheat flour. Comparison of experimental results is also presented in the video to strengthen students' understanding. The results showed that the students' post-test scores increased significantly. The video demonstration is effective to convey material on the differences in the mechanical characteristics of sago crackers made with various ratios of sago flour and wheat flour. This research hopes that the method can improve students' understanding of chemical composition's effect on food's mechanical characteristics. The other hope of this research is to facilitate the abstract material transfer, train student skills, improve student learning outcomes, and support distance learning.

\section{Method}

\subsection{Sago crackers production Method}

\subsubsection{Materials Preparation}

The ingredients used in making sago crackers are sago flour, wheat flour, butter, salt, sugar, cheese and baking powder. The materials used are obtained from local market in Indramayu, West Java, Indonesia.

\subsubsection{Sago Crackers Production}

Figure 1 shows the process of making sago crackers. Sago crackers are made by varying the composition ratio of sago flour and wheat flour, that are 20:80; 40:60; 50:50; and $75: 25$. Samples A, B, C, and D were used respectively to call the sago crackers made with sago flour: wheat flour in the ratio of $20: 80 ; 40: 60 ; 50: 50$; and 75:25. Sago flour and wheat flour are mixed according to predetermined ratios. The mass of the mixture of sago flour and wheat flour was kept constant at $100 \mathrm{~g}$ for all variations. Baking powder is added to the mixture. $20 \mathrm{~g}$ of sugar, and $6 \mathrm{~g}$ of salt are added. $15 \mathrm{~g}$ of chilled butter was added to the mixture to add a savory flavour. The material mixture then knead. $50 \mathrm{~mL}$ of cold water was added to the dough so that the dough become smooth. Then, grated cheese is added to the dough. The dough is kneaded back and flattened. The dough is then molded and baked at $180^{\circ} \mathrm{C}$ for 15 minutes.

\subsubsection{Mechanical Properties Analysis}

To evaluate the mechanical characteristics of sago crackers, the crackers crispness and hardness test was carried out using a screw stand test instrument (Mode I ALX-J, China) equipped with a measuring instrument (a Digital Force gauge (Model HP-500, Serial No. H5001909262), and puncture test using the Shore Durometer instrument (Shore A Hardness, In size, China). The compressive test is carried out by applying a compressive force to the crackers. The test instrument measured the hardness of the crackers. The measurement results are converted into curves, the level of hardness is expressed by the value of the peak of the curve (maximum force) in Newton $(\mathrm{N})$ units. The puncture test is done by inserting a needle into the surface of the sago crackers so that the crackers become hollow. Needle puncture depth is converted to a number.

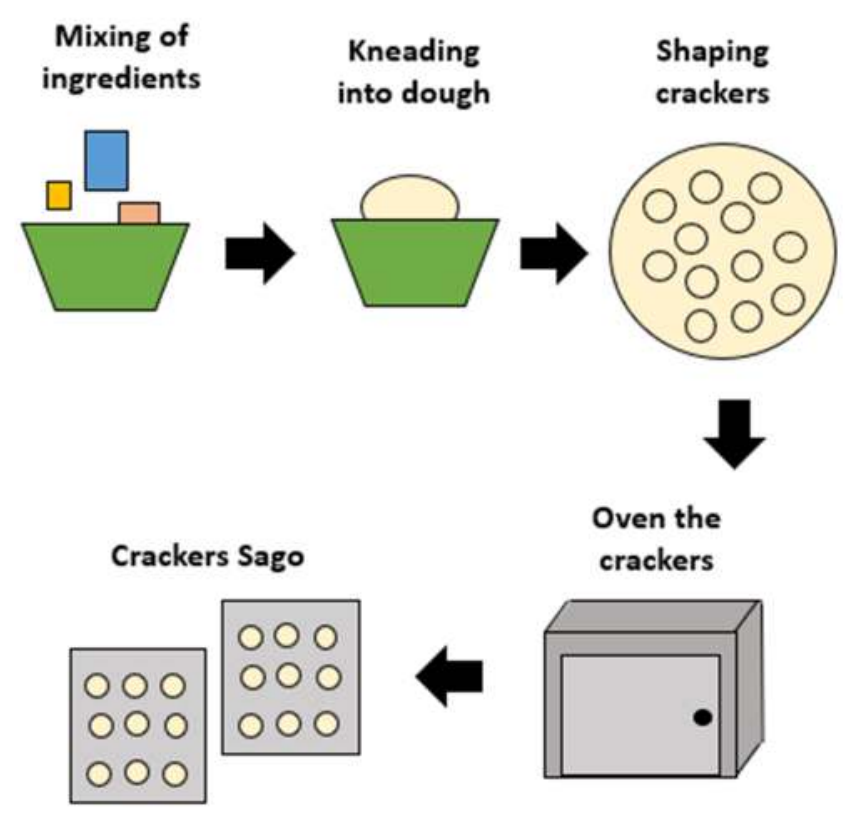

Fig. 1 Illustration of crackers production

\subsection{Teaching Method}

This study uses an experimental demonstration learning method. The experimental demonstration trial was conducted on 20 high school students in Indramayu Regency, Indonesia. The subjects are students in grades 10 and 11 . These students consist of 18 females and 2 males. The average age of the students are 17 years old. The experimental demonstration trial was carried out in three stages.

i. Students are given pre-test questions to analyze their initial knowledge about the effect of flour on crackers making 
ii. Students are then given a video explaining about the effect of nutritional content on flour and other ingredients on the quality of crackers. The video also explains the evidence of mechanical test results.

iii. Students are then given a post-test to see their understanding of the effect of flour on crackers making after being given the video. The T-test was carried out to seeing the significance of the post-test results.

The pre-test and post-test questions given were the same questions consisting of 10 questions. The type of question given is a question statement with a true or false answer. Students must analyse the question statement and determine whether the question is true or false. The analysis score was 1 if the student answered correctly and 0 if the student answered incorrectly. The maximum score in this analysis is 100. Basic information on students was collected to support the research instrument, that are IQ test scores, and the average scores for mathematics, chemistry, physics, and biology. The questions for the pre-test and post-test were:

1. Sago is one of the staple food sources in Indonesia. Sago contains lots of carbohydrates.

2. Apart from containing carbohydrates, sago is also high in protein.

3. Wheat flour contains less protein than sago flour.

4. The nutritional content of food affects the texture, savory taste, and sweetness of the food. Sago is widely used as a raw material for making foods. The carbohydrate content in the food affects the hardness of the food.

5. In making crackers, protein is a factor that affects the texture of the crackers (for example, being soft, firm, or hard).

6. Fat affects the savory taste of food.

7. Crackers can be made with a mixture of wheat flour and sago flour. The higher the sago flour content, make the harder of the crackers

8. Crackers can be made with a mixture of wheat flour and sago flour. The higher of wheat flour content, make the harder of the crackers.

9. The less flour content in the crackers, make the texture of the crackers more brittle.

10. Crackers made with a ratio of 20:80 sago flour and wheat flour are harder than crackers made with a ratio of 40:60.

\section{Results and Discussion}

Photographs of crackers made using various comparisons of sago flour and wheat flour are presented in Figure 2. Figure 2 (a, b, c, and d) respectively are the physical view of the samples A, B C, and D. The physical appearance of the crackers of each sample looks similar. Each sample was given a sprinkling of granulated sugar on top to enhance the appearance of the crackers. Figure 2 (e, f, $\mathrm{g}$, and $\mathrm{h}$ ) respectively are the external view of samples $\mathrm{A}, \mathrm{B}$, $\mathrm{C}$, and $\mathrm{D}$ under the microscope. The outside view of each sample looks solid. Figure $2(I, j, k, 1)$ are respectively the inside view of samples A, B, C, and D under the microscope. All samples show a hollow surface. Morever, sample A has ansformations, Volume No 34, December, 2020, eISSN 2394-1707
a smaller and less porous. While sample D has more and larger porous.

\subsection{Mechanical Properties of Sago Crackers}

Figure 3 shows the results of the compressive test. Compositions in the material influenced the mechanical properties of the material (Nandiyanto, Fiandini, Ragadhita, Sukmafitri, Salam, and Triawan, 2020). More of the sago flour content make the lower hardness of the sago crackers. The highest level of hardness was obtained in sample A which was made with the least sago flour content, that is the ratio of sago flour: wheat flour 20:80. The results of this compressive test are in line with the results of the puncture test.

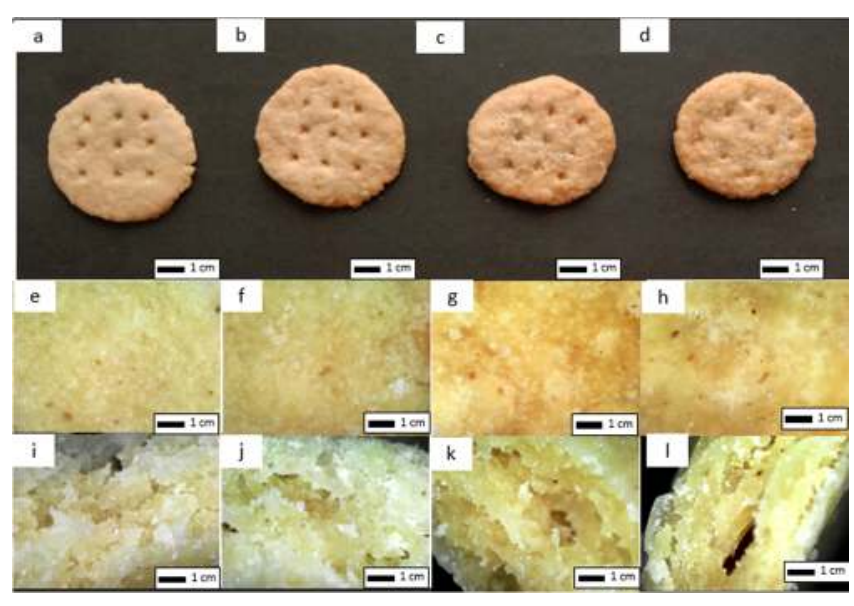

Fig. 2 (a, b, c, and d) the physical view of the samples A, B C, and D, $(e, f, g$, and $h$ ) the external view of samples $A, B, C$, and $D$ under the microscope, $(I, j, k, l)$ the inside view of samples $A, B, C$, and D under the microscope

The puncture test results are presented in Table 1. Sample A shows a small average puncture test result, this is because the harder of sago crackers make it more difficult for the needle to pierce the surface of the sago crackers. The highest average puncture test value is indicated by sample D which was made with the most sago content, that is the ratio of sago flour: wheat flour 75:25. Sample D has the lowest hardness level so that the needle is easier to puncture the surface of the sago crackers. The level of hardness of sago crackers is influenced by the nutritional content and chemical composition of the flour used (Lucky, Al-Mamun, Hosen, Toma, and Mazumder, 2020).

Sago flour has a protein content of $0.19-0.25 \%$ (Konuma, Rolle, and Boromthanarat, 2012). Meanwhile, wheat flour has a protein content of $8 \%$ (Tjokrokusumo, Octaviani, and Saragih, 2019). The high protein content makes for a small expansion resulting in less cavity in the sago crackers. This causes the sago crackers to get harder (Huda, Leng, and Herpandi, 2010). The cavity in sago crackers is also affected by the amylose and amylopectin content.

Sago flour contains 31\% amylose and $73 \%$ of amylopectin (Konuma, Rolle, and Boromthanarat, 2012). Meanwhile, wheat flour contains $10.23 \%$ and $89.77 \%$ amylopectin. Amylose and amylopectin content affects the solubility and gelatinization properties of flour. The greater 
of the amylose-amylopectin content in flour causes the dough to absorb more water (Imaningsih, 2012). The amylose-amylopectin content in sago flour is higher than tapioca flour, so that the sago crackers dough made with the most sago composition (sample D) absorbs more water. However, when the dough is baked, the water in the dough evaporates and leaves the porous in the sago crackers. This is confirmed by microscopic observations in Figure 2. The large number of porous causes the sago crackers to become increasingly brittle. Thus, the more sago composition in the sago crackers, the more crunchy of the sago crackers.

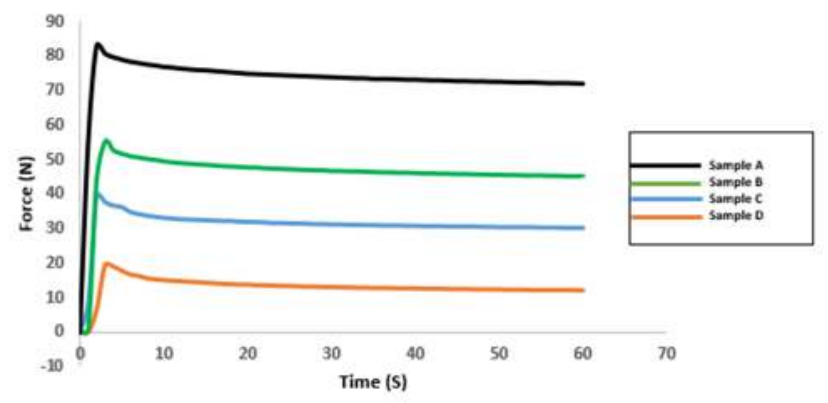

Fig. 3 Compressive test of sample A, B, C, and D

\subsection{Qualitative Analysis of Student}

Figure 4 shows the results of the students' IQ tests. The distribution of the IQ of students shows a normal distribution, so that the sample used in this study can be accepted and represents the population. The average IQ score of the 20 students indicated a normal IQ. A normal IQ indicates good intelligence and can receive science material well.

Table 1. Puncture test of sample A, B, C, and D

\begin{tabular}{|c|c|c|c|c|}
\hline \multirow{2}{*}{ No } & \multicolumn{4}{|c|}{ Sample } \\
\cline { 2 - 5 } & A & B & C & D \\
\hline 1 & 46 & 57 & 62 & 70 \\
\hline 2 & 48 & 58 & 61 & 84 \\
\hline 3 & 47 & 59 & 64 & 86 \\
\hline 4 & 47 & 49 & 63 & 71 \\
\hline 5 & 46 & 53 & 60 & 68 \\
\hline 6 & 46 & 50 & 65 & 80 \\
\hline Average & 46.6 & 54.3 & 62.5 & 76.5 \\
\hline
\end{tabular}

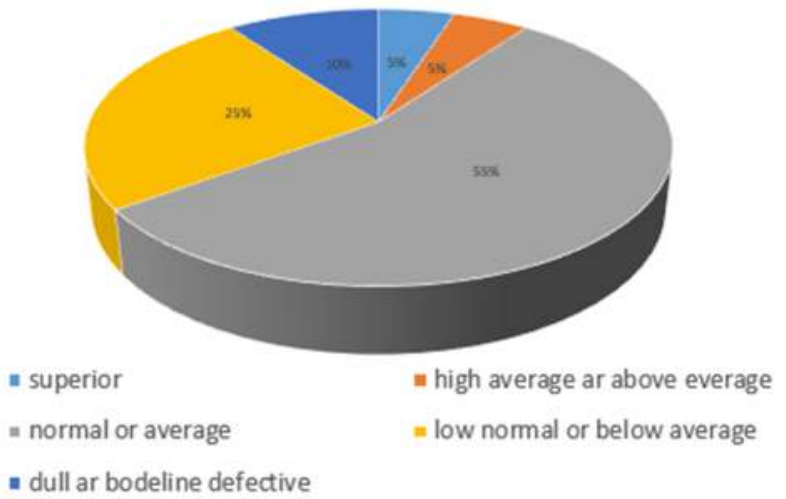

Fig. 4 Distribution of students' IQ score

Table 2 shows the students 'abilities in science subjects supported by basic score on science such as mathematics, physics, chemistry, and biology which show an average score above 80 . This score is quite good in describing the background of students' good learning abilities.

Table 2. Students' average score at school

\begin{tabular}{|c|c|}
\hline Subject & Average Score \\
\hline Mathematics & 85.64 \\
\hline Chemistry & 84.58 \\
\hline Physics & 83.69 \\
\hline Biology & 85.04 \\
\hline
\end{tabular}

Figure 5 shows the pre-test and post-test scores. The post-test score shows an increase from the pre-test after the student being given the learning video. From Figure 5, the experimental demonstration method with the presentation of learning videos has a positive impact on improving students' understanding of the nutritional content and chemical composition of the mechanical characteristics of sago crackers. The experimental demonstration using video gives the audio and visual to transfer the difficult subjects. The method is facilitating the student to improve their focus and imagine the abstract material (Hidayat, Rahmat, Fattah, Rochyadi, and Nandiyanto, Maryanti, 2020).

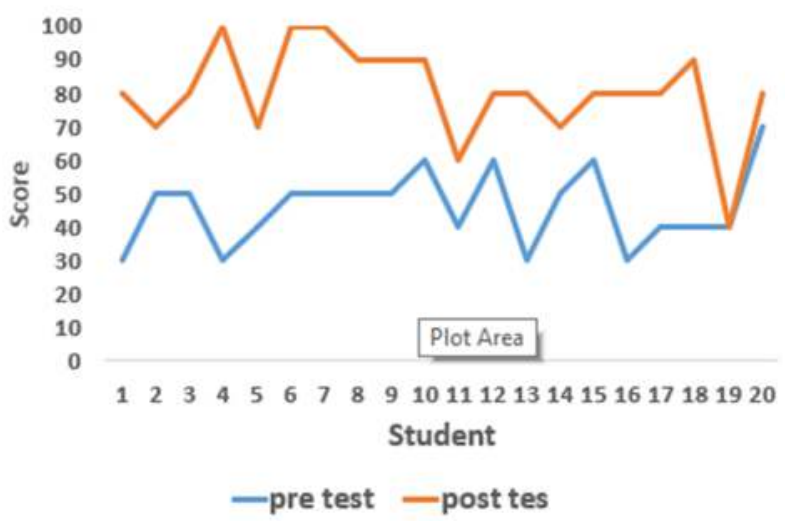

Fig. 5 The average of students' score

The pre-test results were compared with the post-test. The calculated T value (2.093) is greater than the T table ($8.911)$, which states that the post-test score of students 
increases significantly (Alekseyenko, 2016). The result shows that the experimental demonstration learning method using video learning is useful in studying science.

Demonstration videos have a positive impact on increasing student motivation (Bourgonjon, Valcke, Soetaert, and Schellens, 2010). Before the students are given the video, the students did not understand about the relationship of food nutritional and chemical content in the food to the mechanical characteristic. The student's lack of understanding is evidenced by the low pre-test scores. After watching the video demonstration that discusses the things that were asked in the pre-test, students became more interested in the effect of nutrients and chemical composition on the mechanical characteristic of food. The video is presented abstract material with visualization and audio about the experiment in making sago crackers with a variety of composition of sago flour and wheat flour. In the video, the experimental results are also presented so that they can strengthen students' understanding of the effect of nutrients on the mechanical character of food. Thus, the students' posttest scores improved after viewing the demonstration video.

The increase in the Post-test score was caused by the video demonstration method presented to attract students' attention. Demonstration videos are interesting because they relate to things that can be found in everyday life (Wang and Antonenko, 2017). In line with the literature, the experimental demonstration method using video is effective to improve student learning outcomes (Suprianto, Ahmadi, and Suminar, 2019). This experimental demonstration method is especially relevant for use in distance learning.

However, the experimental demonstration methods also have drawbacks. The experimental video demonstration is no more effective than the direct experimental method (Visvawom and Joby, 2017). However, learning will be more optimal if it combines that two methods (blandid learning).

\section{Conclusion}

In this study, learning outcomes of highs chool students in mechanical characteristics and chemical composition of food were observed. The result showed that the hardness of the sago crackers decreases with the amount of sago flour content. The student post-test score increased significantly. The experimental demonstration method using video is effective to improve students' understanding of the effect of chemical composition on the mechanical character of food.

\section{Acknowledgements}

We would like to thank Universitas Pendidikan Indonesia for supporting this research.

\section{References}

Alekseyenko, A. V. (2016). Multivariate Welch t-test on distances. Bioinformatics, 32(23), 3552-3558.

Bourgonjon, J., Valcke, M., Soetaert, R., and Schellens, T. (2010). Students' perceptions about the use of video games in the classroom. Computers \& Education, 54(4), 1145-1156.

Donkin, R., Askew, E., and Stevenson, H. (2019). Video feedback and e-Learning enhances laboratory skills and engagement in medical laboratory science students. BMC medical education, 19(1), 310 .

Hidayat, D. S., Rahmat, C., Fattah, N., Rochyadi, E., and Nandiyanto, A., Maryanti, R., (2020). Understanding Archimedes Law: What the Best Teaching Strategies for Vocational High School Students with Hearing Impairment. Journal of Technical Education and Training, 12(1), 229-237.

Huda, N., Leng, A. L., Yee, C. X., and Herpandi, H. (2010). Chemical Composition, Color and Linear Expansion Properties of Malaysian commercial fish cracker ('keropok'). Asian Journal of Food and Agro-Industry, 3(05), 473-482.

Imanningsih, N. (2012). Profil gelatinisasi beberapa formulasi tepung-tepungan untuk pendugaan sifat pemasakan (Gelatinisation profile of several flour formulations for estimating cooking behaviour). Nutrition and Food Research, 35(1), 13-22.

Jokela, J., Nurmi, J., Genzwuerker, H. V., and Castrén, M. (2009). Laryngeal tube and intubating laryngeal mask insertion in a manikin by first-responder trainees after a short video-clip demonstration. Prehospital and disaster medicine, 24(1), 63-66.

Katsuya, O., and Kadir, A. R. (2018). Business development strategy of sago for food security. E\&ES, 196(1), 012013.

Konuma, H., Rolle, R., and Boromthanarat, S. (2012). Adding value to underutilized food resources: substituting wheat flour with sago flour in cookie formulations. Journal of Agricultural Technology, 8(3), 1077.

Lucky, A. R., Al-Mamun, A., Hosen, A., Toma, M. A., and Mazumder, M. A. R. (2020). Nutritional and sensory quality assessment of plain cake enriched with beetroot powder. Food Research, 4(6), 2049-2053.

Nandiyanto, A. B. D., Fiandini, M., Ragadhita, R., Sukmafitri, A., Salam, H., and Triawan, F. (2020). Mechanical and biodegradation properties of cornstarchbased bioplastic material. Materials Physics and Mechanics, 44, 380-391.

Nandiyanto, A. B. D., Raziqi, G. Y., Dallyono, R., and Sumardi, K. (2020). Experimental Demonstration for Enhancing Vocational Students' Comprehension on Heat Transfer through Conduction and Radiation of Light Bulb. Journal of Technical Education and Training, 12(3), 189-195.

Nishio Z, Ito M, Takata K, Goshima D, Matsushita K, Nakamura T, Yamauchi H. (2020). Analysis of the relationship between various soft wheat flour characteristics and cookie quality. Food Science and Technology Research. 26(2), 215-222.

Saeleaw, M., and Schleining, G. (2010). Effect of blending cassava flour, rice, waxy rice and wheat flour on physicochemical properties of flour mixtures and mechanical and sound emission properties of cassava crackers. Journal of Food Engineering, 100(1), 12-24.

Sever, S., Oguz-Unver, A., and Yurumezoglu, K. (2013). The effective presentation of inquiry-based classroom 
experiments using teaching strategies that employ video and demonstration methods. Australasian Journal of Educational Technology, 29(3), 450-463.

Suprianto, A., Ahmadi, F., and Suminar, T. (2019). The development of mathematics mobile learning media to improve students' autonomous and learning outcomes. Journal of Primary Education, 8(1), 84-91.

Tingginehe, R. M., Hadju, V., Djide, M. N., and Jafar, N. (2016). The influence of consumpting rhyncophorus bilineatus var papua against raising nutritional status for cd4 blood of patients with hiv/aids in papua province year. International Journal of Research, 9(1), 2307-2083.

Tjokrokusumo, D., Octaviani, F. C., and Saragih, R. (2019). Fortification of Mung bean (Vigna radiata) and Ear mushroom (Auricularia auricula-judae) in dried sago noodles. Journal of Microbial Systematics and Biotechnology, 1(2), 34-40.

ViSwASom, A. A., and Jobby, A. (2017). Effectiveness of video demonstration over conventional methods in teaching osteology in anatomy. Journal of Clinical and Diagnostic Research: JCDR, 11(2), 9-11.

Wang, J., and Antonenko, P. D. (2017). Instructor presence in instructional video: Effects on visual attention, recall, and perceived learning. Computers in Human Behavior, 71(2017), 79-89.

Yusuf, M. M., Amin, M., and Nugrahaningsih, N. (2017). Developing of instructional media-based animation video on enzyme and metabolism material in senior high school. JPBI (Jurnal Pendidikan Biologi Indonesia), 3(3), 254-257. 